\title{
The Influence of Entrepreneurial Characteristics on Small and Medium-Sized Enterprise Accessibility to Debt Finance in Nigeria
}

\author{
Olekamma Kingsley Chinonso, Tang Zhen \\ Business school Hohai University, Nanjing China
}

\begin{abstract}
Small and Medium-sized Enterprises (SMEs) play a great role in the economic growth and development, poverty reduction, income generation, and job creation in both developing and developed countries. Despite all these important roles, SMEs still face challenges, particularly in developing countries. Among these challenges, insufficient of debt financing is one of the major challenges. The study determines the influence of entrepreneurial characteristics on access to debt finance by SMEs from banks in Nigeria. The data was collected through a survey done by administering questionnaires to SMEs operators in Nigeria, with a sample population of 110. Pearson correlation and logistic regression statistical analysis were chosen to ascertain the association between independent and dependent variables and whether all the independent variables influence SMEs access to finance. The result revealed that entrepreneur's educational background, managerial competency, networking, entrepreneur age, gender and entrepreneur marital status influences access to finance. The study recommends that the government agencies in charge of SMEs development should organize more training and seminars for SMEs to improve on their shortcomings.
\end{abstract}

Keywords: entrepreneurial characteristics, debt financing, small and medium-sized enterprises (SMEs)

\section{INTRODUCTION}

Small and medium enterprises (SMEs) are catalysts to national economic growth and development because they significant contribution towards poverty reduction, GDP growth, diversification production and job creation in both developed and developing countries. Although accurate data are difficult to be obtained. [1] states that about 95\% of enterprises across the world are SMEs, accounting about $60 \%$ of private sector employment. Furthermore, SMEs are known to be key players in wealth generation, innovation, industrial restructuring and economic development and growth [2]. According to [3], SMEs also contribute significantly to the internationalization process in matured economies. A large number of big companies started from SMEs and some of them even rely on SMEs. For instance, some SMEs are very active in many fields such as, small-series productions and the service industries [4]. In every nation, SMEs represents a vast and economically significant sector of potential businesses. [5] states that SMEs contributed to more than half of the national output in some middle-income countries.

In Nigeria, there are more than 37 million registered SMEs which employ about $84.02 \%$ of the total labor force, contributing to $48.47 \%$ to national GDP growth and $7.27 \%$ to national total export[6].

Despite the great significant contribution of SMEs towards economic development in Nigeria, availability and accessibility of credits from commercial banks has become a major challenge inhibiting the SMEs' growth and development. Although there are other major challenges affecting SMEs development such as lack of management skills, inadequate social infrastructures, and multiple taxations. This was supported by a research done by [7] which indicated that absence of adequate financing is a major obstacle to the entrepreneurial process in any firm regardless of size, type or location of economic activity. SMEs access to finance from financial institutions are poor because the default rates among them are high and due to inadequate financial facilities[8]. According to[9]information asymmetry and proper financial records are another area of constraint, which tends to hinder the flow of credit to SMEs. SMEs operators more often have more information concerning the potential of their own businesses but find it difficult to give detailed information about their business as the lenders want. In addition, many SMEs operators often restrain when it comes to providing banks with detailed information about their business since they afraid that their business 
information may be leaked to their competitors and government agencies such as "internal revenue service"(IRS) [10].

Most of the banks in developing countries prefer to lend money to government and big companies rather than SMEs borrowers because the risk involved is lesser and have higher returns [11], such uncaring attitude to SMES have crowded out many SME operators and increased the cost of capital for them. The situation is equally the same in Nigeria where commercial banks always prefer to lend money to the government, big companies, and trade in foreign exchange. These preferences and habits of the banks have worsened easy accessibility to debt finance by SMEs in Nigeria.

Financial institution is very important to SMEs growth and development in any country, and also has the potential to meet SMEs financial needs, but there is still existence of a huge gap between supply (commercial banks) and demand (SMEs).

Entrepreneurial characteristics are those factors which can positively or negatively influence SMEs accessibility to finance. Entrepreneurial characteristics include; educational background, managerial competency, networking, entrepreneur's age, gender and entrepreneur's marital status. An analysis of the literature on SMEs financing challenges in Nigeria revealed that there is no empirical study done before on the influence of entrepreneurial characteristics on SMEs accessibility to debt finance from commercial banks. Therefore this study is to fill the gaps in the literature and also help to improve easy accessibility of credits to SMEs.

\section{Objective of the Study}

SMEs play great impacts in economic growth and development debt financing. Therefore objectives of this research are to examine empirically the influence of entrepreneurial characteristics on SMEs accessibility to debt finance in Nigeria.

\section{LiterATURE REVIEW}

Previous studies finds out that reducing challenges hindering external financing for SMEs contributes to economic growth, reduced poverty and reduced income inequality $[12,13]$. Paulson and Townsend [14] states that increasing the channels of financing at the firm level can enhance employment generation, entrepreneurial activities, income, and innovation. In accessing external finance, it is widely agreed by many authors that SMEs encounter more difficulties than the larger firms, this challenges hinders their innovation and growth $[15,16]$. In addition, previous studies on access to finance by SMEs indicated that not only perceived accessibility of credits and the cost of finance seems to a big hindrance, but these factors have more relatively negatives influence on their performance compared to the large firms $[16,17]$. Poor capital causes SMEs to seek external finance to increase their production, develop new line of products, increase their labor force and buy new equipment. [18] revealed that banks are more exposed to larger firms, compared to smaller firms, and most times banks charge SMEs high-interest rates and fees than large enterprises.

[19] claims that acuteness of asymmetric information between commercial banks and small firms as one of the main hindrances for SMEs have easy access to loans in Sub-Sahara Africa. [20] also states that moral hazard and information asymmetry influences on finance accessibility and capital structure of SMEs.

Information asymmetry challenges can be solved by having long-lasting 'relationship banking', where banks obtain soft information through repeated conversations with the firm owners. Some examples of soft information includes, the behavior and reliability of the firms' owner; the future prospects of the SME gathered from past conversations with SME's suppliers, neighboring or customers businesses and the credit history of the firm garnered from the previous transactions; [21].

\subsection{Policies and Programs to Promote SMES Growth in Nigeria}

SMEs in Nigeria are also facing many challenges like others in developing countries. Because of the great role SMEs are playing in economic development and growth, most of countries supports their SMEs which includes; infrastructure, supportive services, commercial finance, information training and retraining, venture capital, research and development (R\&D) support and tax incentives.

Since 1970, Nigerian government created various initiatives, incentives, packages, opportunities and support enhance SMEs credits access. 
The Influence of Entrepreneurial Characteristics on Small and Medium-Sized Enterprise Accessibility to Debt Finance in Nigeria

Tab1. Government Policies and Programs to Promote Snes Growth in Nigeria

\begin{tabular}{|l|l|}
\hline Name of SMEs Support Institutions & Year of Establishment \\
\hline Mandatory Credit Guideline in respect of SMEs (MCGS) & 1970 \\
\hline Small Scale Industries Credit Scheme (SSICS) & 1971 \\
\hline Nigerian Bank for Commerce and Industries (NBCI) & 1973 \\
\hline Nigerian Industrial Development Bank (NIDB) & 1964 \\
\hline SME Apex Unit of Central Bank & 1990 \\
\hline National Economic Reconstruction Fund (NERFUND) & 1989 \\
\hline The African Development Bank/ Export Stimulation Loan (ADB/ESL) & 1989 \\
\hline Nigerian Export-Import Bank (NEXIM) & 1991 \\
\hline National Directorate of Employment (NDE) & 1986 \\
\hline Community Banks & 1990 \\
\hline People's Bank & 1989 \\
\hline Family Economic Advancement Program (FEAP) & 1997 \\
\hline Small and Medium Industries Equity Investment Scheme (SMIEIS) & 2001 \\
\hline Bank of Industry (BOI) & 2001 \\
\hline Small and Medium Enterprises Developing Agency of Nigeria (SMEDAN) & 2003 \\
\hline Micro-finance banks & 2004 \\
\hline SMEs Credit Guarantee Scheme & 2010 \\
\hline
\end{tabular}

Source: Author Computation

Despite all these institutions, SMEs still find it difficult to find external finance. This makes Nigeria Government to introduce the one recent support scheme i.e. The SME Credit Guarantee Scheme (SMECGS).

\subsection{Small and Medium Scale Enterprises Credit Guarantee Scheme (SMECGS)}

SMECGS was established in 2010 by Central Bank of Nigeria (CBN), to provide a guarantee for credits advanced to the SMEs by commercial banks. The scheme shall guarantee $80 \%$ of principal and interest and shall be valid until the maturity date of the loan with at most tenure of 7 years inclusive of 2-year moratorium. 500 billion naira has so far been approved since the establishment of the scheme. The objectives of the scheme include:

1. To provide loans guarantee from commercial banks to SMEs.

2. To fast-track the growth and development of the SME sector in Nigerian.

3. Set the step for industrialization of the Nigerian economy.

4. To enhance SMEs and some large manufacturing firms access to credit.

5. To increase output and foreign exchange earnings, create employment.

6. To diversify the revenue base and provide inputs for the industrial sector on a sustainable basis.

\section{CONCEPTUAL FramewOrk}

The conceptual framework is a structure that supports theory of the research work. The theory is a formulation concerning the effect and cause associations between two or more variables, which may or may not have been tested.

The conceptual framework of this study centered on the influence of entrepreneurial characteristics on SMEs accessibility to debt finance in Nigeria. The variables from this conceptual framework hypothetically were tested to establish whether there were any significant relationships between independent variables and dependent variable.

The independent variables of this study are educational background, managerial competency, networking, entrepreneur's age, gender and entrepreneur's marital status while the dependent variable 
is the access to finance by SMEs.

\section{Conceptual Framework}

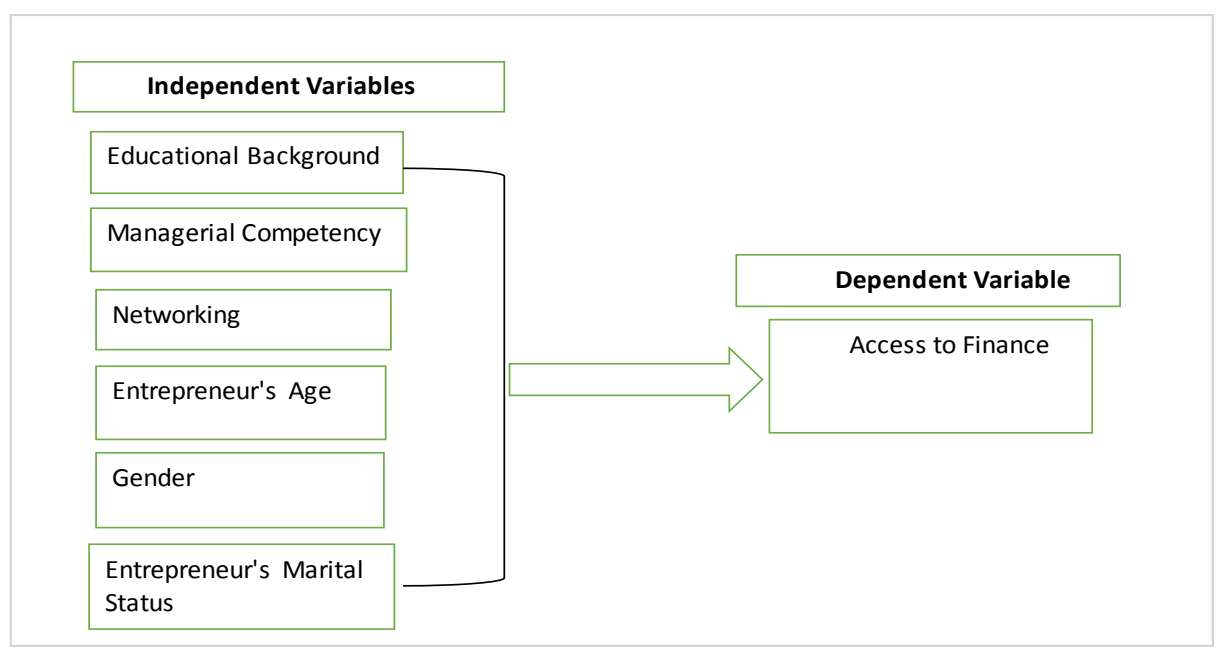

\section{Entrepreneurial Characteristics}

Entrepreneurial characteristics are among the three major characteristics that can influence SMEs accessibility to finance from banks in Nigeria. Factors that constitute entrepreneurial characteristics are as follow:

\section{Educational Background}

There is existing positive relationship found between higher educational qualifications and business growth [22]. Education helps to enhance communication skills, improve skills and foresight. These skills enhancement are positively associated with presenting a credible case for a loan to a banker at the time of preparing a loan proposal and therefore convince the banker during the client interview [23].

Past study has probed the way managerial educational level influences access to debt finance from banks. A research conducted by[24] finds out that high educational level of firm's manager/owner influence easy accessibility to financial service in Brazil . They also discovered that university graduates had fewer challenges to raise finance from banks. The researchers gave interpretations for their findings. They stated that high educated firms' owner/managers have the ability to provide strong business plans and positive financial information and they are capable to maintain and sustain cordial relationship with commercial banks compared to less educated ones. Most of the educated entrepreneurs have skills to manage other business functions includes human resources, finance, marketing, and these skills results to high business performance, hence helps those firms to have access to credits without many difficulties. Some banks in Nigeria value entrepreneurs with a higher level of education. Thus, there is a positive association between education background and access to debt finance.

\section{Managerial Experience}

[25] pointed out that managerial experience, knowledge and startup experience of the business positively influence firms' performance. Furthermore, [2] explains that firms' owners with previous experience are more likely to avoid some costly mistakes than those ones with no prior experience, hence they are better placed in accessing credits.

In Nigeria, lack of management skills is also major challenges to the survival of SMEs, this lack of managerial skills effect SMEs in getting finance from commercial banks. Thus, managerial experiences and access to debt finance by SMEs are significantly related.

\section{Networking}

[26] observed that networks can also be used as the solutions to overcome the challenges of access to limited resources and markets. Networks can help to provide information, advice and capital to SMEs. Small firms being associated with a trade union, professional bodies or other social associations such as societies and clubs, may influence easy accessibility to debt finance [23]. There is evidence that good relationship between SMEs and banks can minimize information asymmetry constraint [27] and 
The Influence of Entrepreneurial Characteristics on Small and Medium-Sized Enterprise Accessibility to Debt Finance in Nigeria

reduce loan interest rates [28]. Thus it is hypothesized that networking positively influences SMEs access to credits.

Gender

Previous researches revealed that that gender of firms' owner can influence the capital structure choice of firm. [29] argues that discrimination and risk aversion are also reasons that effect women-owned firms on access to debt finance. [30] finds that firms owned by women in the United States of America have lower loan acceptance and application rates than male's owned enterprises. [31] found that more collateral was required by women to secure loans than what was demanded of their male counterparts. [32] suggests that gender may influence a lender's decision to provide loans to the borrowers. [33] expressed that a firm managed by female is less likely to have access to bank finance. This suggests that the banks claim that female-owned enterprises create more risks than the male counterpart. Thus, it is hypothesized that gender has positively impact on access to debt finance by SMEs.

\section{Firms' Owner Age}

Firms' owner age is one of the major factors that affect SMEs to access to bank finance. The age effect on accessing bank credits can be seen from both loans' borrower and lender side. [34]states that age determines firm's owner/manager choice of either being user or non-user in the financial market. This is because some age groups tend to prefer and act differently than other age groups. Older firms' owners don't want to use external finance from banks because they commonly appear to create a risk to them [35]. Similarly, from lender's perspective, banks have different perception on age groups what also affects access to bank finance. Old age entrepreneurs are perceived as non-dynamic and non-innovative. Banks also perceived that young entrepreneurs are more innovative and good performers, but with risky portfolio [36]. Information asymmetry decrease while firm's owner age increase in the factors that influence SMEs access to finance [37]. [38] pointed out that age highly influences on firms' ability to access banks credits. From above discussion we can conclude that firm's owner age has positive significant on access to bank finance by SMEs.

\section{Entrepreneur's Marital Status}

Firms' owner marital status also influences SMEs easy accessibility to debt finance from banks in Nigeria. During the survey of this study, a banker in one of the commercial banks in Nigeria, states that when other factors are constant, married SME operator tends to have easy access to loans. [39] states that in Jamaica, married status has an influence on the financial success of small business owners, because they exhibits respect, higher, social status, and important networking capabilities representative of social capital. [39], also observed that married status was expected to create more social capital advantages in the availability of resources for the small business owners than unmarried ones. In above discussions, we observed that married status is important in accessing finance by SMEs. Therefore there is an association between firms' marital status and access to credits from banks in Nigeria.

\section{Firm's Access to Finance}

SMEs significantly impact on economic growth and development of any nation, hence access to finance provides more opportunities for SMEs to grow and develop. SMEs access to credits can be an incentive to spur knowledge of creativity and innovation. Many SMEs in Nigeria fails within few years of their establishment because of lack of finance. In Nigeria there are many finance sources available, among which commercial banks are the major ones. The above empirical review has highlighted entrepreneurial characteristics as the major factors that influence SMEs' access to finance.

\section{Material AND Methods}

The empirical study focused on Lagos state and Anambra State in Nigeria because the two states are considered as the most industrialized, hence with larger SMEs. Data collection was done through a survey questionnaire comprising open-ended and closed-ended questions. The sample size of the study was 150 , but 110 respondents completely filled the questionnaires and returned it. The statistical Package for Social Sciences (SPSS) $20^{\text {th }}$ version was used to analyze the data. The research questionnaire was pre-tested through a pilot study covering 35 respondents. The pre-testing process helped to identify whether the questionnaire met research objectives and if the questionnaire needed corrections or not. The statistical analysis descriptive, Pearson correlation, and logistic regression statistics were used to analyze the data. 


\section{The Study Modeled That:}

Access to finance $=f$ (educational background, manager experience, networking, manager age, gender, marital status)

Thus, $\mathrm{AF}=\mathrm{EB}+\mathrm{ME}+\mathrm{Net}+\mathrm{EA}+\mathrm{Gen}+\mathrm{EMS}$

$\mathrm{AF}=\beta 0+\beta 1 \mathrm{~EB}+\beta 2 \mathrm{ME}+\beta 3 \mathrm{Net}+\beta 4 \mathrm{EA}+\beta 5 \mathrm{Gen}+\beta 6 \mathrm{EMS}+\mathrm{U}$

Where:

$\mathrm{AF}=$ Access to finance

$\mathrm{EB}=$ Educational background

$\mathrm{ME}=$ Manager Experience

Net $=$ Networking

$\mathrm{EA}=$ Entrepreneur age

Gen $=$ Gender

EMS $=$ Entrepreneur marital status

$\mathrm{U}=$ Stochastic

\section{ReSUlts AND DiscuSSION}

150 questionnaires were administered and 110 respondents returned their questionnaires, representing $73 \%$ of total research population. The questionnaire was structured to catch up respondents in SME sectors that have gone for debt finance before. The study assesses how the entrepreneurial characteristics influence access to finance by SMEs in Nigeria.

\section{Reliability Results}

Cronbach's alpha reliability statistics is a research instrument that indicates the degree to which the research is without bias, hence ensured the consistent measurement across time and several items within instrument[40]. Cronbach's alpha Tab coefficient was used to establish the internal consistency of the scale that was used to measure the reliability level of the variables of the study. Cronbach's alpha of 0.6 was regarded satisfactory, while 0.7 to 0.8 considered good[41].

Tab3. Reliability Statistics

\begin{tabular}{|l|l|}
\hline Cronbach's Alpha & N of Items \\
\hline .787 & 6 \\
\hline
\end{tabular}

Person's Correlation Analysis of Variables

Correlation analysis was conducted to determine the degree of correlation between the variables intended for this study. The variables were: Educational background, managerial experience, networking, firm owner's age, gender and entrepreneur's marital status. In order to establish the association of the variables; correlation analysis was run first, to determine if the relationship existed between the dependent variable and independent variables as well to know whether multi-collinearity existed among the independent variables.

The result of correlation analysis show that: Educational background $(r=0.437 ; \mathrm{p}=0.00)$, Managerial experience $(r=0.666 ; p=0.00)$, Networking $(r=0.701 ; p=0.00)$, Entrepreneur's age $(r=0.728 ; p=$ $0.00)$, Gender $(r=0.599 ; p=0.00)$, Entrepreneur's marital status $(r=0.629 ; p=0.00)$. The above independent variables show that they are all positively correlated with access to finance. The results also indicated that accessibility of finance from commercial banks in Nigeria is positively influenced by entrepreneurial educational background, managerial experience, networking, entrepreneur's age, gender, and entrepreneur's marital status.

Furthermore, the correlation coefficients indicate that among the variables there is no multicollinearity. Multicollinearity problem arises when the correlation coefficient between predictors is than 0.90 ( $\mathrm{r}$ $=>0.90$ ). 
The Influence of Entrepreneurial Characteristics on Small and Medium-Sized Enterprise Accessibility to Debt Finance in Nigeria

Tab4. Correlations

\begin{tabular}{|c|c|c|c|c|c|c|c|c|}
\hline & & $\mathrm{AF}$ & EB & ME & Net & EA & Gen & EMS \\
\hline \multirow{2}{*}{$\mathrm{AF}$} & Pearson Correlation & 1 & $-.437^{* *}$ & $-.666^{* *}$ & $.701^{* *}$ & $-.728^{* *}$ & $.599^{* *}$ & $-.629^{* *}$ \\
\hline & Sig. (2-tailed) & & .000 & .000 & .000 & .000 & .000 & .000 \\
\hline \multirow{2}{*}{ EB } & Pearson Correlation & $-.437^{* *}$ & 1 & $282^{* *}$ & $-.347^{* *}$ & $371^{* *}$ & $-.267^{* *}$ & .175 \\
\hline & Sig. (2-tailed) & .000 & & .003 & .000 & .000 & .005 & .067 \\
\hline \multirow{2}{*}{ ME } & Pearson Correlation & $-.666^{* *}$ & $282^{* *}$ & 1 & $-.532^{* *}$ & $.598^{* *}$ & $-.425^{* *}$ & $.591^{* *}$ \\
\hline & Sig. (2-tailed) & .000 & .003 & & .000 & .000 & .000 & .000 \\
\hline \multirow{2}{*}{ Net } & Pearson Correlation & $.701^{* *}$ & $-.347^{* *}$ & $-.532^{* * *}$ & 1 & $-.633^{* *}$ & $476^{* *}$ & $-.512^{* * *}$ \\
\hline & Sig. (2-tailed) & .000 & .000 & .000 & & .000 & .000 & .000 \\
\hline \multirow{2}{*}{ EA } & Pearson Correlation & $-.728^{* * *}$ & $371^{* *}$ & $.598^{* *}$ & $-.633^{* *}$ & 1 & $-.546^{* *}$ & $.558^{* *}$ \\
\hline & Sig. (2-tailed) & .000 & .000 & .000 & .000 & & .000 & .000 \\
\hline \multirow{2}{*}{ Gen } & Pearson Correlation & $.599^{* *}$ & $-.267^{* *}$ & $-.425^{* *}$ & $.476^{* *}$ & $-.546^{* *}$ & 1 & $-.476^{* *}$ \\
\hline & Sig. (2-tailed) & .000 & .005 & .000 & .000 & .000 & & .000 \\
\hline \multirow{2}{*}{ EMS } & Pearson Correlation & $-.629^{* *}$ & .175 & $.591^{* *}$ & $-.512^{* *}$ & $.558^{* *}$ & $-.476^{* *}$ & 1 \\
\hline & Sig. (2-tailed) & .000 & .067 & .000 & .000 & .000 & .000 & \\
\hline
\end{tabular}

**. Correlation is significant at the 0.01 level (2-tailed)

\section{Logistic Regression Analysis}

The logistic regression model is used to analyze the relationship between independent dichotomous variables or dichotomous dependent variables due to its flexibility and strongly to violation of the normality assumption within a model [42]. To establish the level of each of these variables influence on the accessibility of debt finance, logistic regression was used to do the analyses.

\section{Educational Background}

The study sought to establish the influence of managerial educational background on access to debt finance from commercial banks by SMEs in Nigeria. Educational background refers the level of education of the firm's owner/manager. Education helps to enhance communication skills, improve skills and foresight. These skills enhancement are positively associated with presenting a credible case for a loan to a banker at the time of preparing a loan proposal and therefore convince the banker during the client interview [23].

The study found out that firm's manager/owner educational background has a positive significant influence on access to debt finance from commercial banks by SMEs in Nigeria. The odd ratio for an entrepreneurial educational background is 0.189 with a p-value 0.033 , and confirmed hypotheses.

\section{Managerial Experience}

Our survey found that managerial experience positively influences access to finance by SMEs in Nigeria. The managerial experience odd ratio is 0.227 with a p-value 0.018 , the result confirmed our hypotheses. [25] pointed out that managerial experience, knowledge and startup experience of the business positively influence firms' performance. A survey conducted by [2] also finds out that firms' owners with previous experience are more likely to avoid some costly mistakes than those ones with no prior experience.

\section{Networking}

Odd ratio of managers/owners networks is 146.425 with a p-value 0.025 , this confirms our hypotheses expectation which states that there is a significant relationship exist between firm's manager/owners network to access debt finance from commercial banks in Nigeria.

[26] observed that networks can also be used as the solutions to overcome the challenges of access to limited resources and markets. Networks can help to provide information, advice and capital to SMEs. Small firms being associated with a trade union, professional bodies or social associations such as 
societies and clubs, may influence to access bank finance [23].

Gender

The study found out that manager's gender has a significant influence on the accessibility of debt finance by SMEs in Nigeria, with odd ratio of 38.252 with a p-value of 0.017 . This is contrary to an earlier survey done by [43] which states that there is no significant differences between men and women in accessibility of debt finance. [44] also states that gender does not influence the accessibility of finance by SMEs.

\section{Entrepreneur's Age}

In our survey the entrepreneur's age odd ratio is 0.163 with a p-value 0.029 , which confirm our hypotheses expectation which states that there is a positive significant relationship exist between entrepreneurs' to access debt finance from commercial banks by SMEs in Nigeria, and it influences access to finance. Our study confirmed by previous studies done by [37]; [38] which states that manager's age increases the factors that influence SMEs accessibility to finance from commercial banks.

\section{Entrepreneur Marital Status}

The study showed that entrepreneur's marital status influences access to finance from commercial banks by SMEs in Nigeria with odd ratio 0.062 and a p-value 0.027. [39] states that in Jamaica, marital status has a positive influence on the financial success of small business owners, because it provides a measure of respectability, social status, and important networking capabilities representative of social capital. [39], also observed that married status was expected to create more social capital advantages in the availability of resources for the small business owners than unmarried ones.

Tab5. Results of Logistic Regression

\begin{tabular}{|c|c|c|c|c|c|c|c|c|}
\hline & $B$ & S.E. & Wald & Df & Sig. & $\operatorname{Exp}(B)$ & $95 \% \mathrm{C}$ & for $\operatorname{EXP}(B)$ \\
\hline & & & & & & & Lower & Upper \\
\hline Edu & -1.667 & .781 & 4.556 & 1 & .033 & .189 & .041 & .873 \\
\hline Man_exp & -1.485 & .630 & 5.549 & 1 & .018 & .227 & .066 & .779 \\
\hline Networking & 4.987 & 2.225 & 5.024 & 1 & .025 & 146.425 & 1.870 & 11464.944 \\
\hline Entre_age & -1.812 & .829 & 4.781 & 1 & .029 & .163 & .032 & .829 \\
\hline Gender & 3.644 & 1.527 & 5.694 & 1 & .017 & 38.252 & 1.918 & 763.073 \\
\hline Marital_status & -2.777 & 1.254 & 4.902 & 1 & .027 & .062 & .005 & .727 \\
\hline Constant & 6.890 & 4.669 & 2.178 & 1 & .140 & 982.036 & & \\
\hline
\end{tabular}

Variable(s) entered on step 1: Edu, Man_exp, Networking, Entre_age, Gender, Marital_status

\section{CONCLUSION AND RECOMMENDATION}

The study has contributed to our knowledge of the factors related to the entrepreneurial characteristics influence on SMEs accessibility to finance from banks in Nigeria. The result of the survey shows that there is interdependence and significant relationship between the entrepreneurial characteristics and accessibility of finance by SMEs.

Given that entrepreneurial characteristics are considered by commercial banks before giving credits to SMEs in Nigeria, SME operators should improve their educational level, try to be connected with trade union or other professional bodies. Lack of managerial experience is also a major reason why SMEs can't access finances from banks in Nigeria. Therefore, to improve access to finance, the SMEs operators need personal development especially in the area of financial management and business skills through training and seminars. Nigeria government agencies such as Small and Medium Enterprises Developing Agency of Nigeria (SMEDAN), Bank of Industry (BOI), Association of Small Business Owners Nigeria (ASBON) and Central Bank of Nigeria (CBN0 should organize more training for SMEs. Nigerian government should also formulate polices that will make banks to relax regulations that scare SMEs away from seeking debt finance from formal financial institution. Finally SMEs operators in Nigeria should have strong network with the banks and other financial institution. 


\section{Limitation of This Study}

The study investigated only internal factors, hence external factors which may also influence accessibility of finance by SMEs should also be investigated, to reveal the level of external factors influence their access to debt finance from banks in Nigeria. Moreover, our study focused on the demand side (borrowers) of access to debt financing by SMEs in Nigeria while suppliers of credits (lenders) were not involved. More contributions could be discovered to create a bridge between demand and supply sides if all parties were involved. The sample size of the study is relatively small due to time constraint and the research was done only in two states out of 36 and capital in Nigeria, it would have been better if the research was extended to more states.

\section{REFERENCES}

[1] Ayyagari, M., A. Demirgüç-Kunt, and V. Maksimovic, Small vs. young firms across the world: contribution to employment, job creation, and growth. World Bank Policy Research Working Paper, 2011(5631).

[2] Storey, D.J., Understanding the small business sector. University of Illinois at Urbana-Champaign's Academy for Entrepreneurial Leadership Historical Research Reference in Entrepreneurship, 1994.

[3] Poutziouris, P., The strategic orientation of owner-managers of small ventures: evidence from the UK small business economy. International Journal of Entrepreneurial Behavior \& Research, 2003. 9(5): p. 185-214.

[4] Wahab, A., Kalsom \& Abdesamed, Khalid. 2012.“. Small and Medium Enterprises (SMEs) Financing Practice and Accessing Bank Loan Issues-The Case of Libya". World Academy of Science, Engineering and Technology. 72: p. 1535-1540.

[5] Seman, N.A.A., et al., Green supply chain management: a review and research direction. International Journal of Managing Value and Supply Chains, 2012. 3(1): p. 1-18.

[6] statistics, N.b.o., SMEs contribution to national economic growth, N.b.o. statistics, Editor 2013, National bureau of statistics: Nigeria.

[7] Westhead, P. and M. Wright, Advances in entrepreneurship. Vol. 3. 2000: Edward Elgar Publishing.

[8] Kauffmann, C., Financing SMEs in Africa. 2005.

[9] Hussain, J. and H. Matlay, Financing preferences of ethnic minority owner/managers in the UK. Journal of Small Business and Enterprise Development, 2007. 14(3): p. 487-500.

[10] Winborg, J. and H. Landström, Financial bootstrapping in small businesses: examining small business managers' resource acquisition behaviors. Journal of business venturing, 2001. 16(3): p. 235-254.

[11] Levitsky, J., Credit guarantee schemes for SMEs-an international review. Small Enterprise Development, 1997. 8(2): p. 4-17.

[12] Rajan, R.G. and L. Zingales, Which capitalism? Lessons form the east Asian crisis. Journal of Applied Corporate Finance, 1998. 11(3): p. 40-48.

[13] Levine, R., Finance and growth: theory and evidence. Handbook of economic growth, 2005. 1: p. 865-934.

[14] Paulson, A.L. and R. Townsend, Entrepreneurship and financial constraints in Thailand. Journal of Corporate Finance, 2004. 10(2): p. 229-262.

[15] Cressy, R., Introduction: Funding Gaps: A Symposium. Economic Journal, 2002: p. F1-F16.

[16] Beck, T. and A. Demirguc-Kunt, Small and medium-size enterprises: Access to finance as a growth constraint. Journal of Banking \& Finance, 2006. 30(11): p. 2931-2943.

[17] Schiffer, M. and B. Weder, Firm size and the business environment: Worldwide survey results. Vol. 43. 2001: World Bank Publications.

[18] Yildirim, H.S., Y. Akci, and I.H. Eksi, The effect of firm characteristics in accessing credit for SMEs. Journal of Financial Services Marketing, 2013. 18(1): p. 40-52.

[19] Osano, H.M. and H. Languitone, Factors influencing access to finance by SMEs in Mozambique: case of SMEs in Maputo central business district. Journal of Innovation and Entrepreneurship, 2016. 5(1): p. 1.

[20] Stiglitz, J.E. and A. Weiss, Credit rationing in markets with imperfect information. The American 
economic review, 1981. 71(3): p. 393-410.

[21] Berger, A.N. and G.F. Udell, A more complete conceptual framework for SME finance. Journal of Banking \& Finance, 2006. 30(11): p. 2945-2966.

[22] Kozan, M.K., D. Öksoy, and O. Özsoy, Growth plans of small businesses in Turkey: Individual and environmental influences. Journal of Small Business Management, 2006. 44(1): p. 114-129.

[23] KUNG'U, G.K., Factors influencing SMEs access to finance: A case study of Westland Division, Kenya. 2011.

[24] Kumar, A. and M. Francisco, Enterprise size, financing patterns, and credit constraints in Brazil: analysis of data from the investment climate assessment survey. Vol. 6. 2005: World Bank Publications.

[25] Hisrich, R.D. and M. Drnovsek, Entrepreneurship and small business research-a European perspective. Journal of Small Business and Enterprise Development, 2002. 9(2): p. 172-222.

[26] Atieno, R., Linkages, access to finance and the performance of small-scale enterprises in Kenya. 2009: Citeseer.

[27] Cole, R.A., The importance of relationships to the availability of credit. Journal of Banking \& Finance, 1998. 22(6): p. 959-977.

[28] Petersen, M.A. and R.G. Rajan, The benefits of lending relationships: Evidence from small business data. The journal of finance, 1994. 49(1): p. 3-37.

[29] Abor, J., Determinants of the capital structure of Ghanaian firms, 2008, African Economic Research Consortium Nairobi.

[30] Mijid, N., Gender, race, and credit rationing of small businesses: Empirical evidence from the 2003 Survey of Small Business Finances. 2009: Colorado State University.

[31] Riding, A.L. and C.S. Swift, Women business owners and terms of credit: Some empirical findings of the Canadian experience. Journal of business venturing, 1990. 5(5): p. 327-340.

[32] Marlow, S. and D. Patton, All credit to men? Entrepreneurship, finance, and gender. Entrepreneurship theory and practice, 2005. 29(6): p. 717-735.

[33] Orser, B.J., A.L. Riding, and K. Manley, Women entrepreneurs and financial capital. Entrepreneurship Theory and Practice, 2006. 30(5): p. 643-665.

[34] Nakano, M. and P. Nguyen, Do older boards affect firm performance? An empirical analysis based on Japanese firms. An Empirical Analysis Based on Japanese Firms (July 6, 2011), 2011.

[35] Le, N.T. and T.V. Nguyen, The Impact of Networking on Bank Financing: The Case of Small and Medium-Sized Enterprises in Vietnam. Entrepreneurship Theory and Practice, 2009. 33(4): p. 867-887.

[36] Ogubazghi, S.K. and W. Muturi, The Effect of Age and Educational Level of Owner/Managers on SMMEs' Access to Bank Loan in Eritrea: Evidence from Asmara City. American Journal of Industrial and Business Management, 2014. 4(11): p. 632.

[37] Abdulsaleh, A.M. and A.C. Worthington, Small and medium-sized enterprises financing: A review of literature. International Journal of Business and Management, 2013. 8(14): p. 36.

[38] Nguyen, N. and N.T.H. Luu, Determinants of Financing Pattern and Access to Formal-Informal Credit: The Case of Small and Medium Sized Enterprises in Viet Nam. Journal of management research, 2013. 5(2): p. 240-259.

[39] Honig, B., What determines success? Examining the human, financial, and social capital of Jamaican microentrepreneurs. Journal of business venturing, 1998. 13(5): p. 371-394.

[40] Kothari, C.R., Research methodology: Methods and techniques. 2004: New Age International.

[41] Sekaran, U. and R. Bougie, Research Methods for Business: A Skilled Approach, 2013, Chichester, UK: John Wiley \& Sons Ltd.

[42] Agresti, A., An introduction to categorical data analysis. Vol. 135. 1996: Wiley New York.

[43] Coleman, S., Access to capital and terms of credit: A comparison of men-and women-owned small businesses. Journal of Small Business Management, 2000. 38(3): p. 37.

[44] Fatoki, O. and F. Asah, The impact of firm and entrepreneurial characteristics on access to debt finance by SMEs in King Williams' town, South Africa. International Journal of Business and Management, 2011. 6(8): p. 170. 